Artefactos

Cómo citar: Híjar, C. (2020). De poéticas y estéticas políticas. En: Mediaciones, 25 (16). Pp. 374-397. https://doi.org/10.26620/uniminuto. mediaciones.16.25.2020.374-397

Editorial: Corporación Universitaria Minuto de Dios - UNIMINUTO

Recibido: 15 de junio de 2020 Aceptado: 20 de agosto de 2020 Publicado: 16 de diciembre de 2020

ISSN: 1692-5688 | eISSN: 2590-8057

Cristina Híjar González

cristinahijardgmail.com

Maestra en Comunicación y Política https://orcid.org/0000-0003-0054-6065 Centro Nacional de Investigación, Documentación e Información de Artes Plásticas del Instituto Nacional de Bellas Artes.

México.

Conflicto de intereses: La autora ha declarado que no existen intereses en competencia.
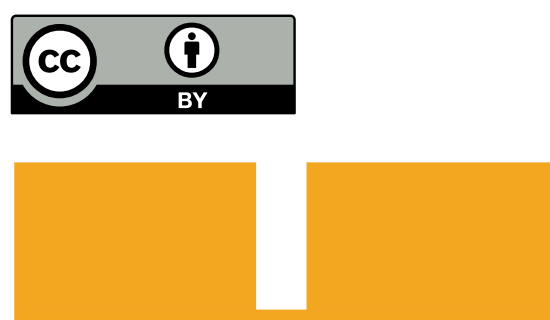

\section{De poéticas y estéticas políticas}

\section{Of poetics and political aesthetics}

\section{Da poética e da estética política}

Por un lado, mis preocupaciones y afanes académicos recientes se han orientado a la dimensión y praxis estética en la movilización social. Por el otro, como sujeto político asumo mi lugar y función social, la conjunción de ambas premisas y elecciones, me ha conducido por los caminos de la investigación participativa.

Coincido con el antropólogo Andrés Aubry quien señala a la empiria como un lugar de producción de conocimientos, lo cual implica estar atentos a todo lo que ocurre a nuestro alrededor; en particular, a todo aquello que se vive en realidades no incluidas en los medios de comunicación masiva, ni en los circuitos oficiales del arte, ni en la academia, al menos no como lo ameritarían las situaciones de emergencia social.

La participación activa, aunada a la visión crítica, produce corpus de investigación susceptibles de ser reflexionados con el objetivo de aportar algo al movimiento, desde mi particular lugar de enunciación y con las herramientas propias de la investigación social y artística. Por ello, practico una etnografía sensorial relativa en cada una de las acciones sociales en las que participo. Documento fotográficamente el universo estético desplegado en cada marcha, en cada acción de memoria, estoy atenta a las narrativas erigidas colectivamente, a los significantes y medios expresivos de la gente, de los actores y agentes políticos inmersos, a los saberes y capacidades diversas puestas al servicio de objetivos comunes que agrupan, convocan, denuncian e interpelan. Mucho ocurre en las calles, en ese espacio público ganado y construido por los empeños colectivos.

Todo está en juego en el discurso social constituido no solo por la palabra escrita o verbal, como bien precisa Robert Fossaert. Significantes variados okupan el espacio, 
el tránsito y los itinerarios de la movilización social, proponiendo sentidos concretos que contribuyen a un común sensible respecto a problemáticas y agravios compartidos y urgentes de atención social.

Las redes y los contagios van tomando forma para dar lugar a vínculos sociales fraternos de considerable alcance, que se concretan en acción política. Ya no basta con la conmoción y la solidaridad intermitentes, coincido con Marcelo Expósito quien propone "la no reconciliación como principio estético", lo cual implica radicalizar nuestras emociones, sensaciones, sentimientos y mentalidades para operar, en cada una y uno de nosotros, una transformación profunda sobre la base de que los cambios que advertimos indispensables para un mejor futuro para todas y todos tienen que sujetarse.

Así, hay quienes ponen el cuerpo individual como significante poderoso, como soporte material de su expresión política; otros organizan y proponen en colectivo; algunos más convocan a realizaciones que solo pueden ocurrir por la suma de todas y todos, y ahí radica la potencia de "las acciones políticas de praxis estética", como definió Roberto Amigo al primer Siluetazo argentino de 1983, definición aplicable a todo este universo que no se reduce a una "obra”, a un "autor”, ni siquiera al ámbito estricto del arte. Son artefactos (por su producción con recursos artísticos), dispositivos (por su forma de operar y puestas en acción) y transformadores, por sus propósitos múltiples: desde la agitación y propaganda, atendiendo a la propuesta de Saint-Simon en el siglo XIX que atribuyó a los artistas la responsabilidad "de proveer la pasión general”, hasta informativos, de denuncia o exigencia, al fin, actos comunicativos en diversos lenguajes y gramáticas.

Esta propuesta es solo una muestra de imágenes visuales cargadas de sentidos compartidos, que dan testimonio de tiempos infames; pero sobre todo de poéticas, estéticas y políticas en lucha. 


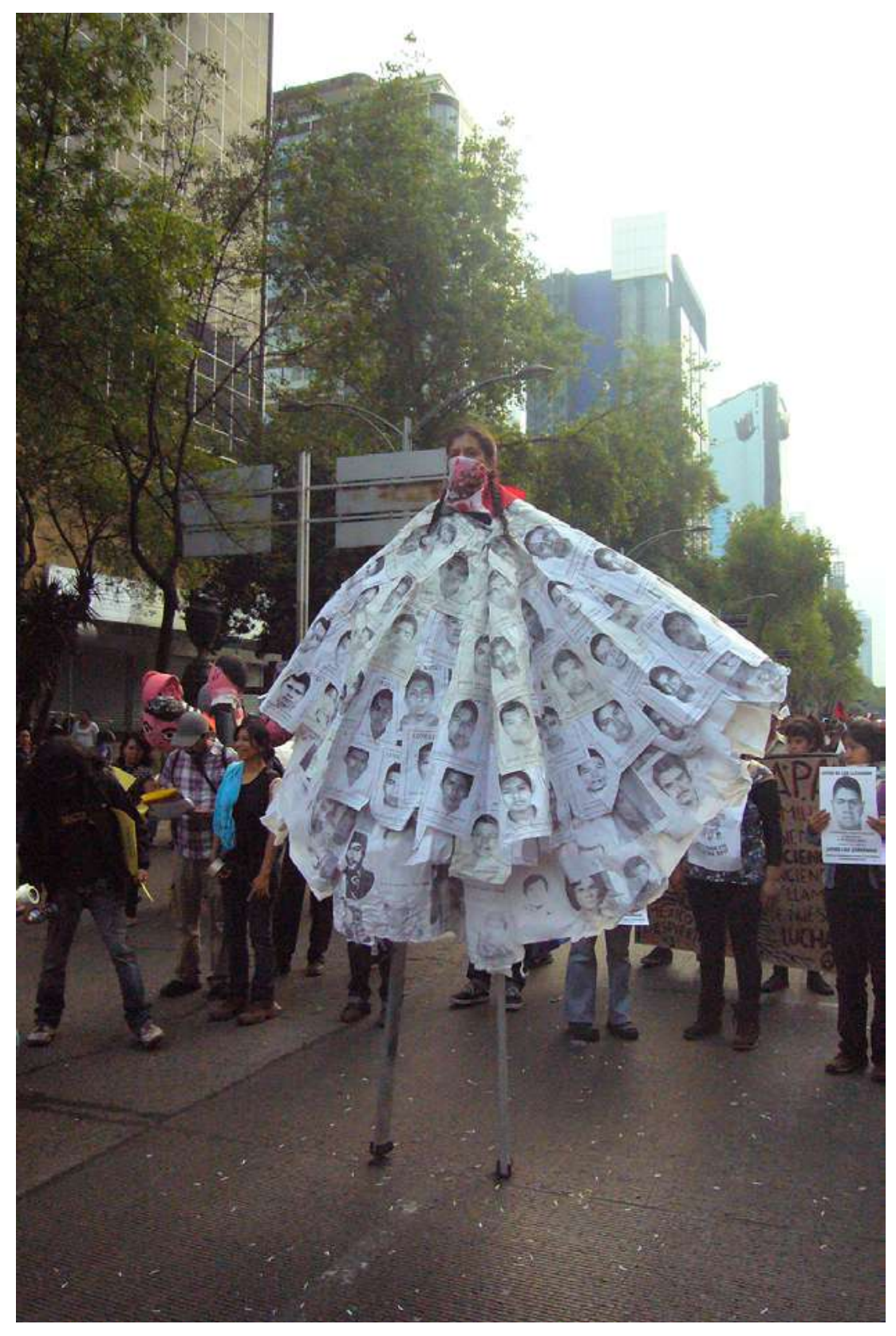

Capa por lxs desaparecidxs del colectivo Chanti Ollin en marcha por Ayotzinapa, 26 enero 2015, Ciudad de México. Fuente: fotografía, Cristina Híjar González 


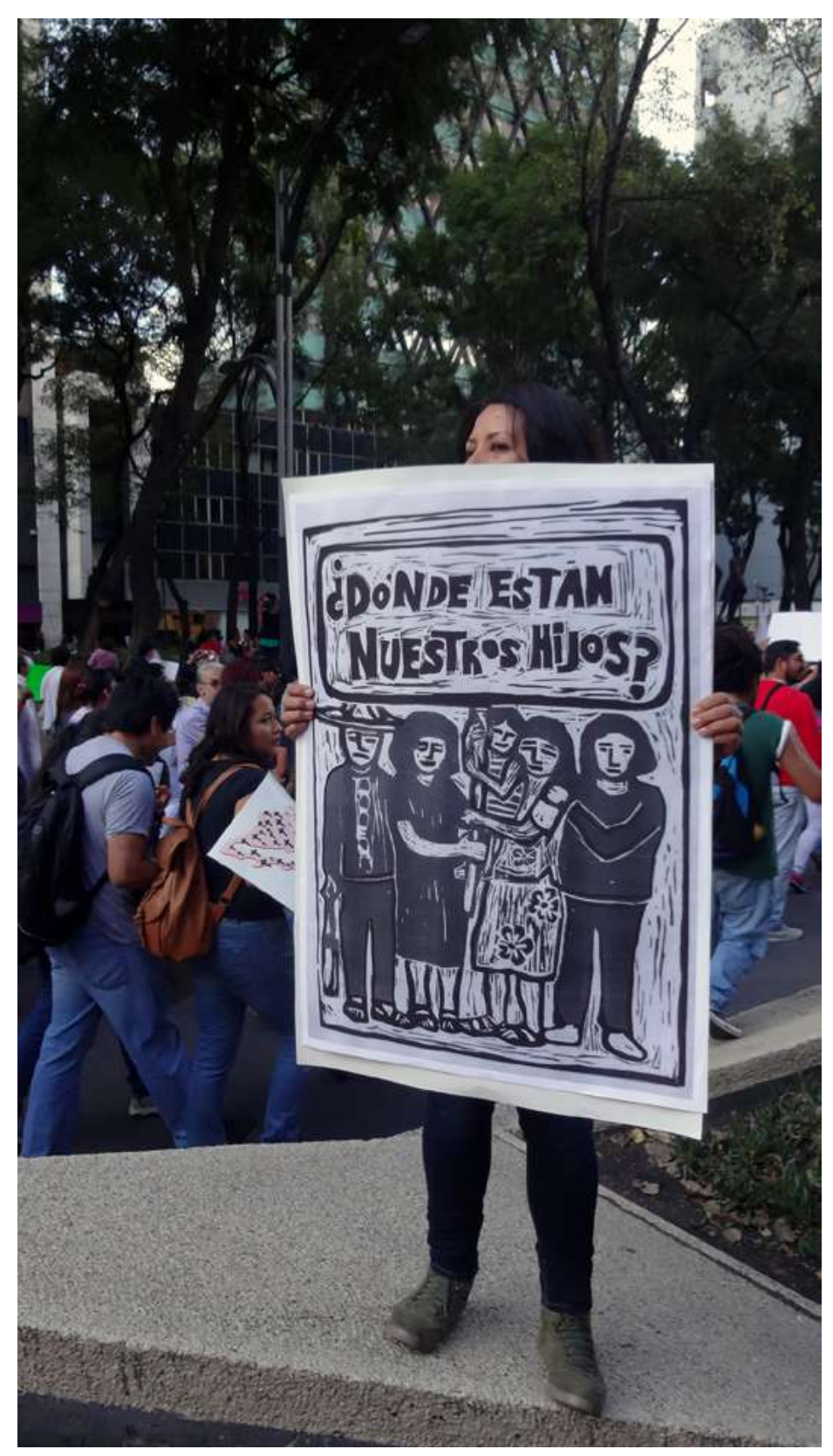

Cartel ¿Dónde están?, impresión comunitaria.

Marcha por Ayotzinapa, 8 octubre 2014, Ciudad de México.

Fuente: fotografía, Cristina Hijar González 


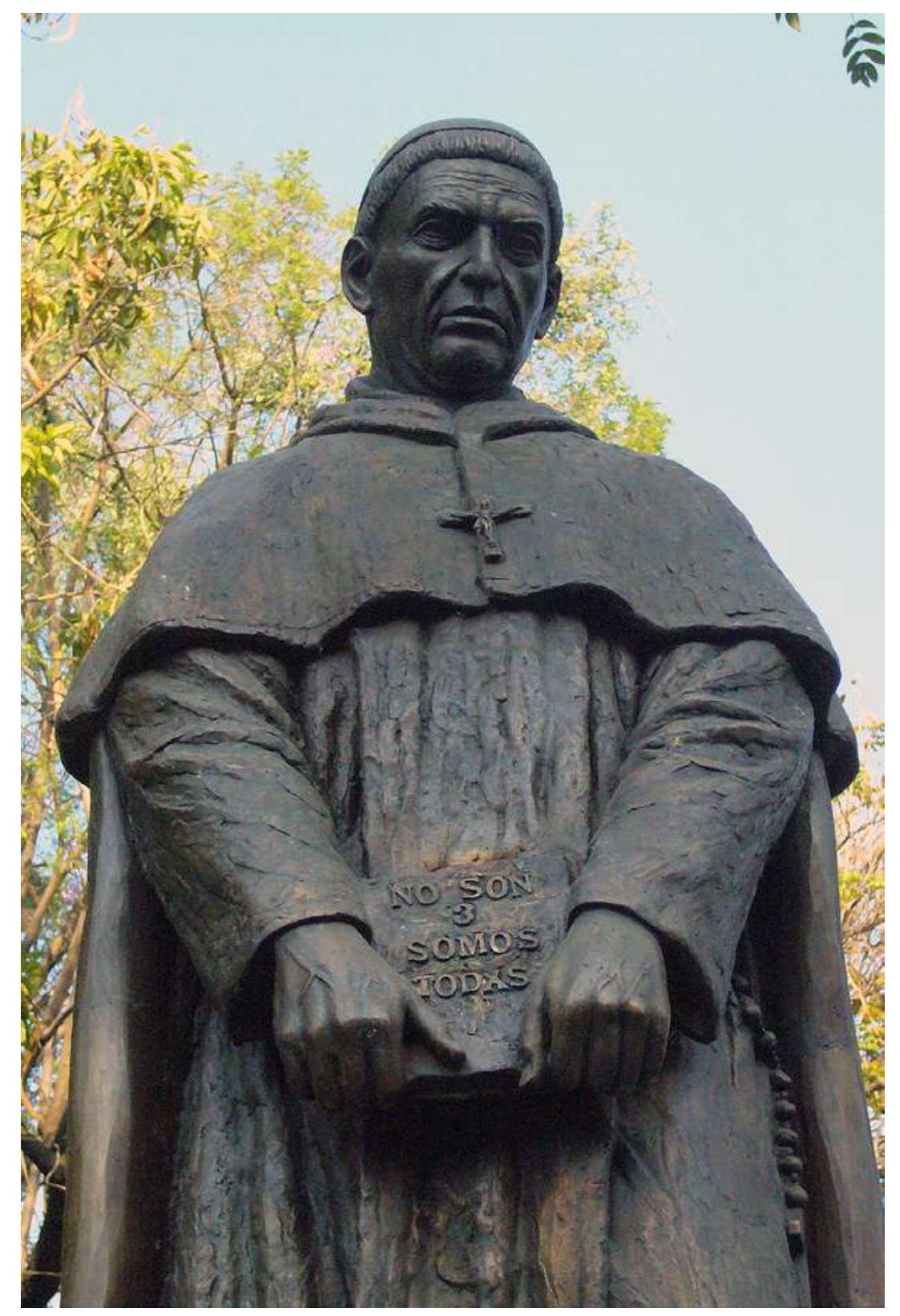

Alfredo López Casanova, Estatua de Fray Antonio Alcalde en la Rotonda de los Jaliscienses Ilustres, Guadalajara, Jalisco. México. Marzo 2019.Al primer año de la desaparición de 3 estudiantes de cine, el escultor, junto con las madres de los jóvenes, develó 4 consignas ocultas en la escultura realizada, meses atrás, por encargo gubernamental, para exigir verdad, justicia y aparición con vida de los estudiantes. Fuente: fotografía, Cristina Híjar González 


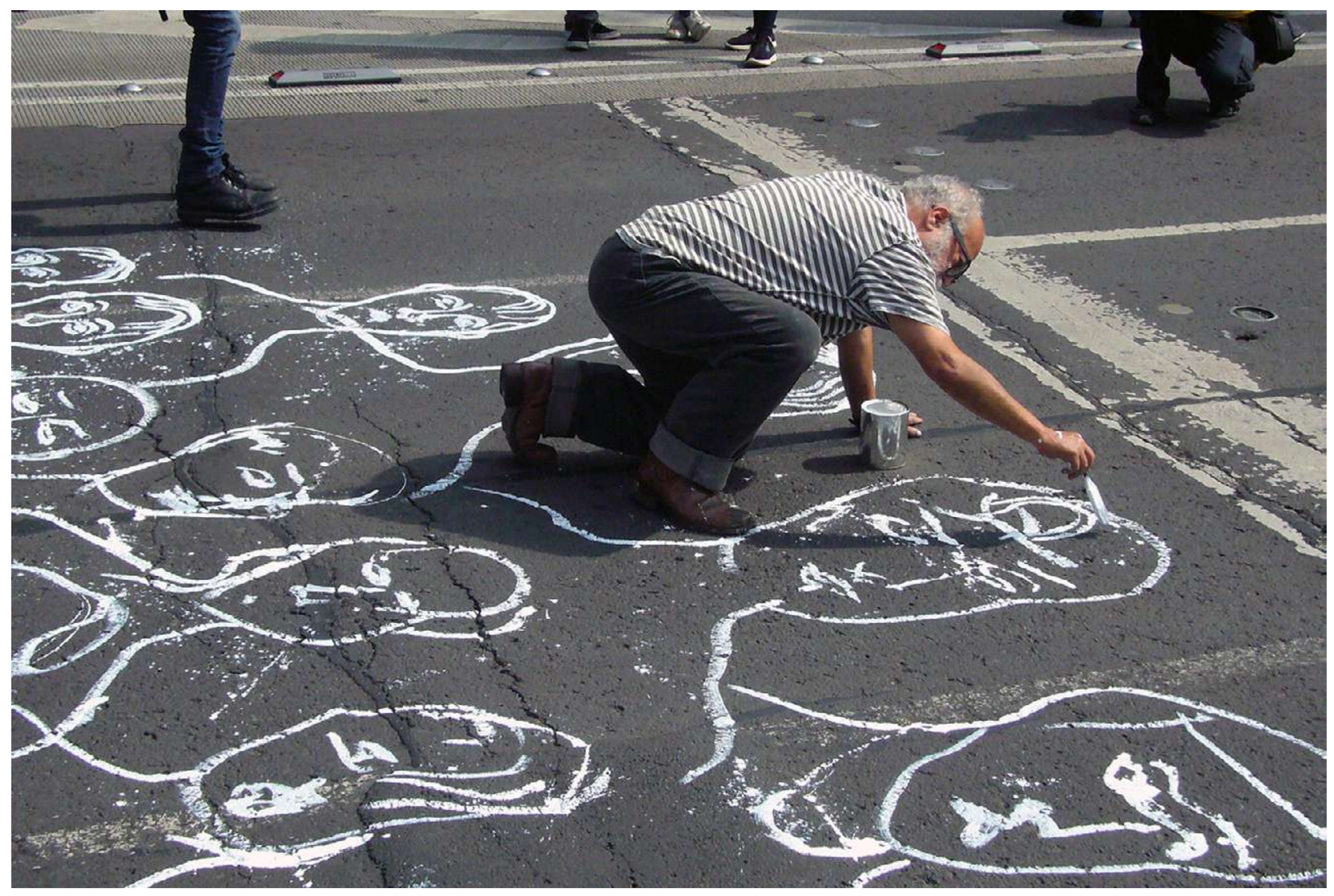

Gabriel Macotela, conocido pintor mexicano, realiza la pinta de 43 rostros sobre el pavimento del Paseo de la Reforma en la marcha por el cuarto aniversario de Ayotzinapa, Ciudad de México, 26 septiembre 2018. Fuente: fotografía, Cristina Híjar González 


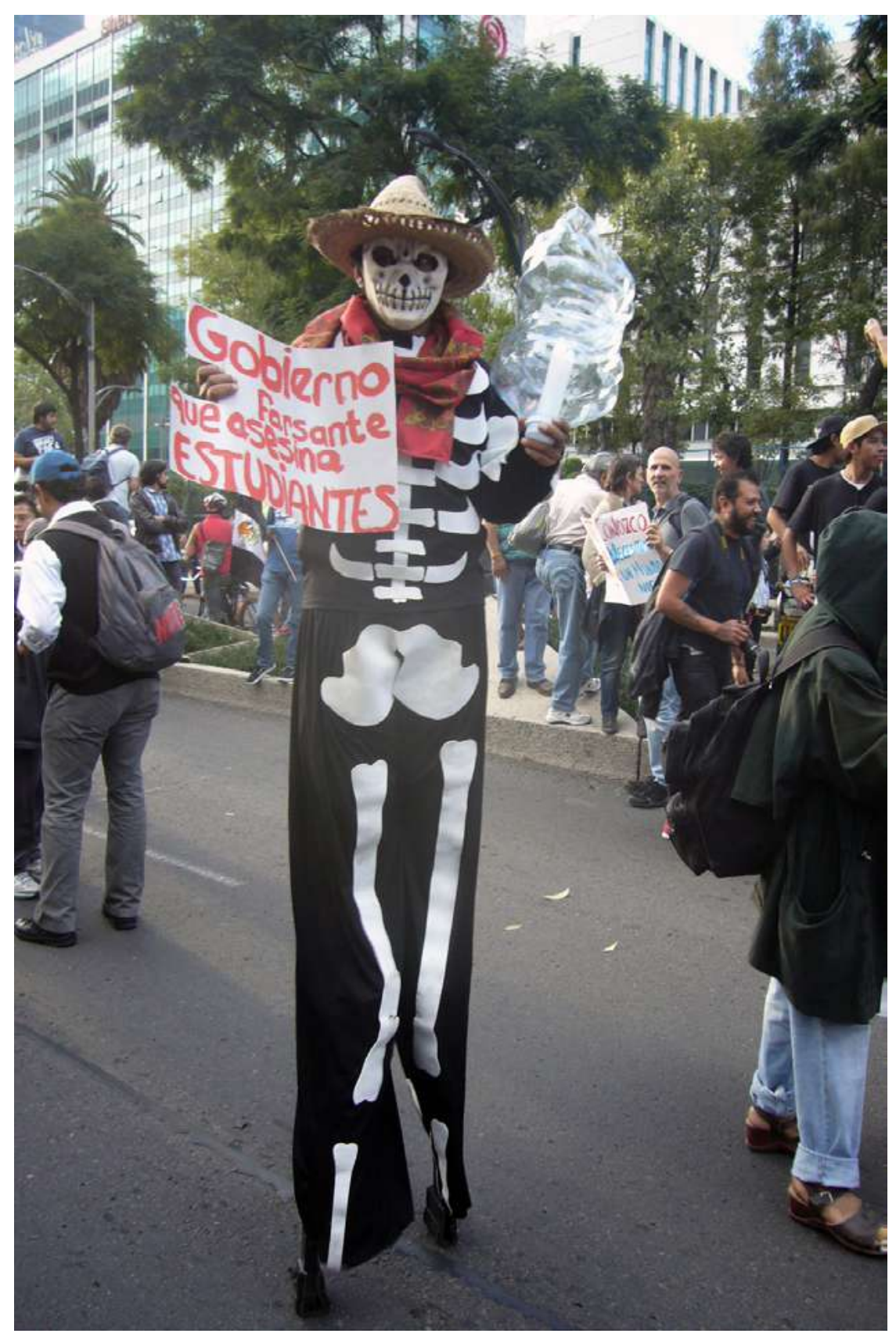

Manifestante en zancos. Marcha por Ayotzinapa, 22 octubre 2014. Fuente: fotografía, Cristina Hijar González 


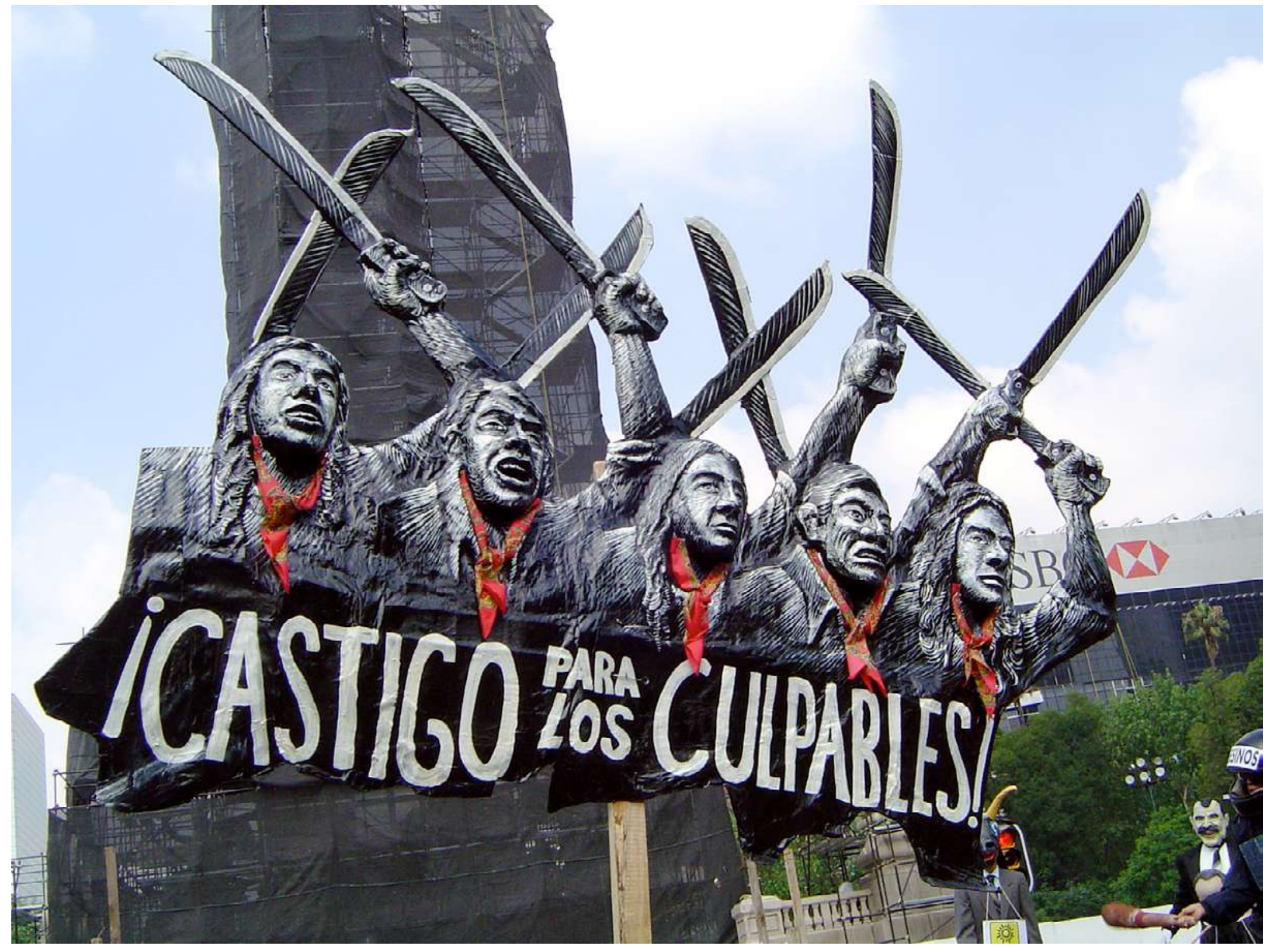

Pancarta tridimensional realizada por el artista visual Rama, portada en marcha contra la represión en Atenco, Estado de México, en la Ciudad de México, 28 mayo 2006. Fuente: fotografía, Cristina Hijar González 


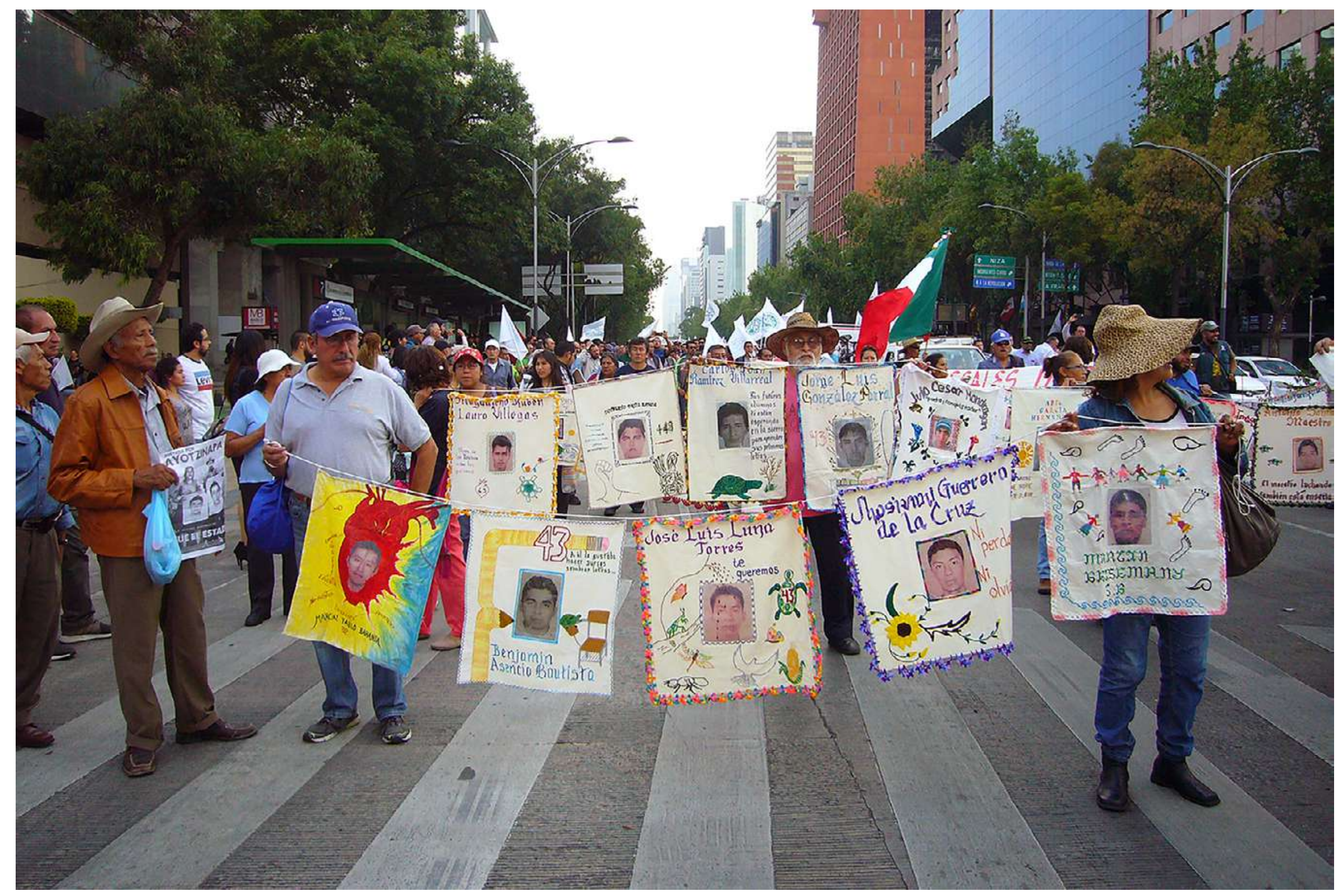

Bordados por los 43 realizados por la Asamblea General de los Pueblos, Barrios, Colonias y Pedregales de Coyoacán, Ciudad de México, marcha mensual por Ayotzinapa, 26 abril 2018.

Fuente: fotografía, Cristina Hijar González 


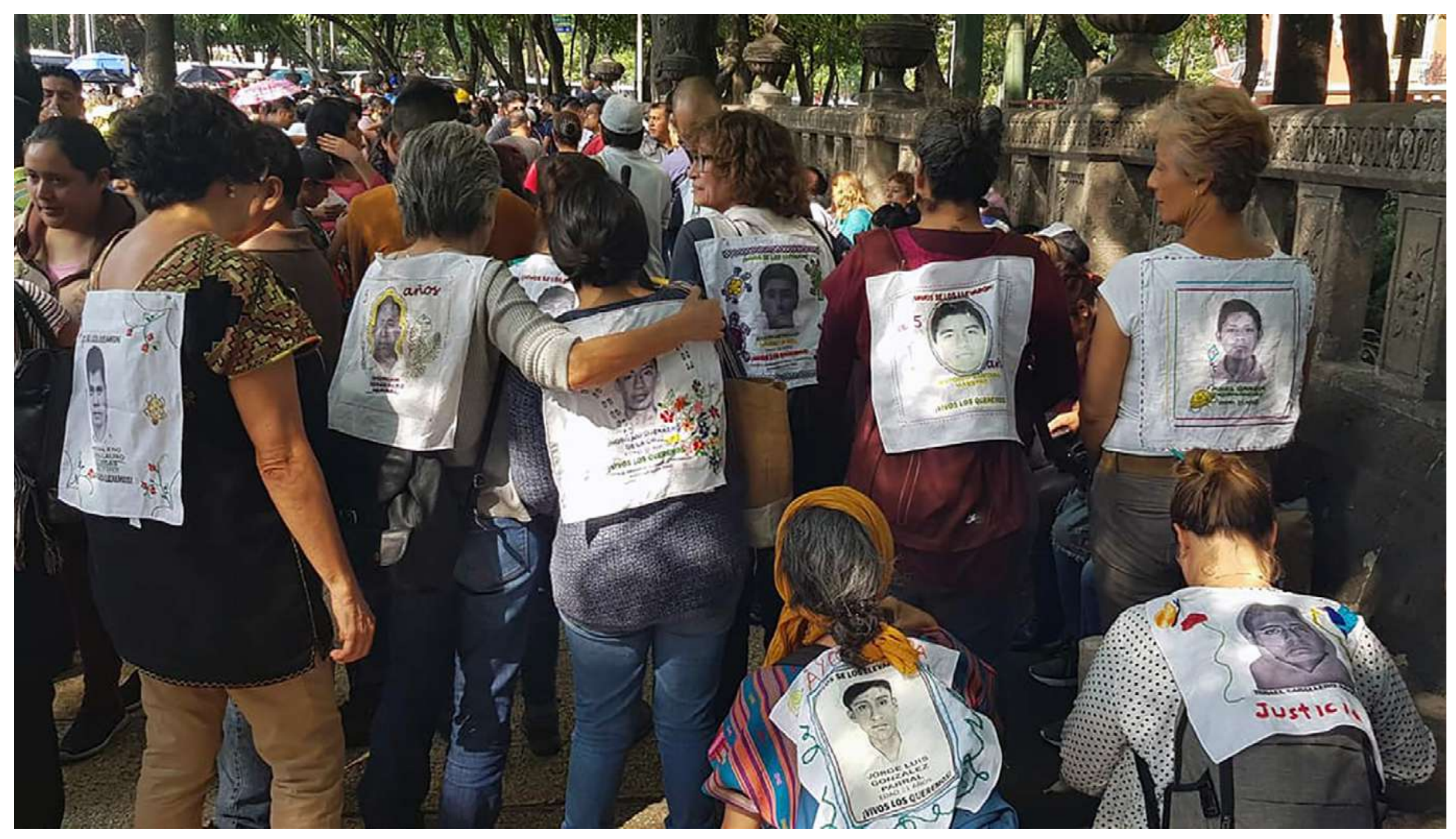

Bordando por la Paz y la Memoria: una víctima, un pañuelo en marcha por el $5^{\circ}$ aniversario de Ayotzinapa, Ciudad de México, 26 septiembre 2019 Fuente: fotografía, Cristina Hijar González 


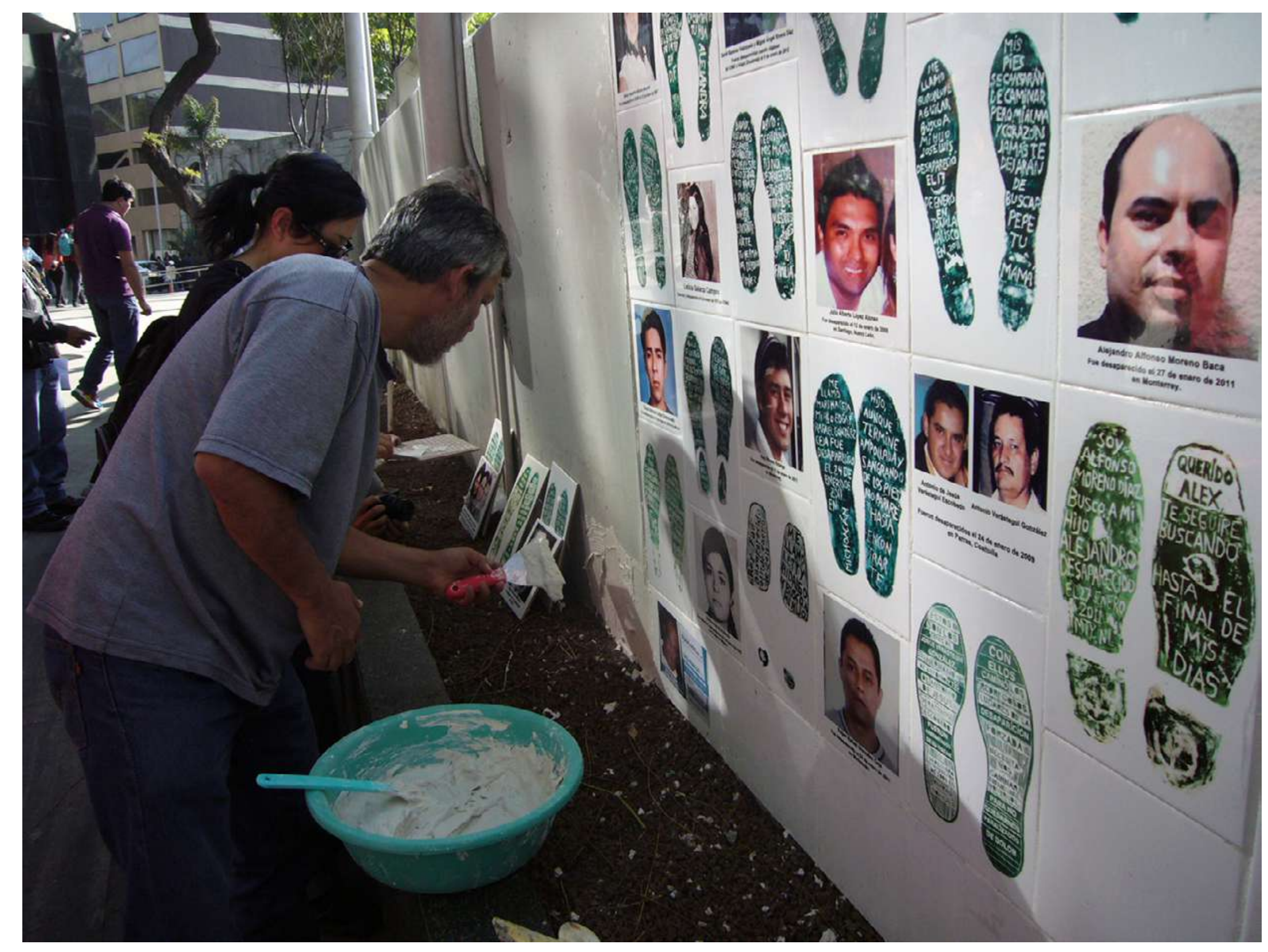

Huellas de la memoria, mural en mosaico en las afueras

de la Fiscalía General de la República, Ciudad de México, 24 febrero 2020.

Fuente: fotografía, Cristina Hijar González 


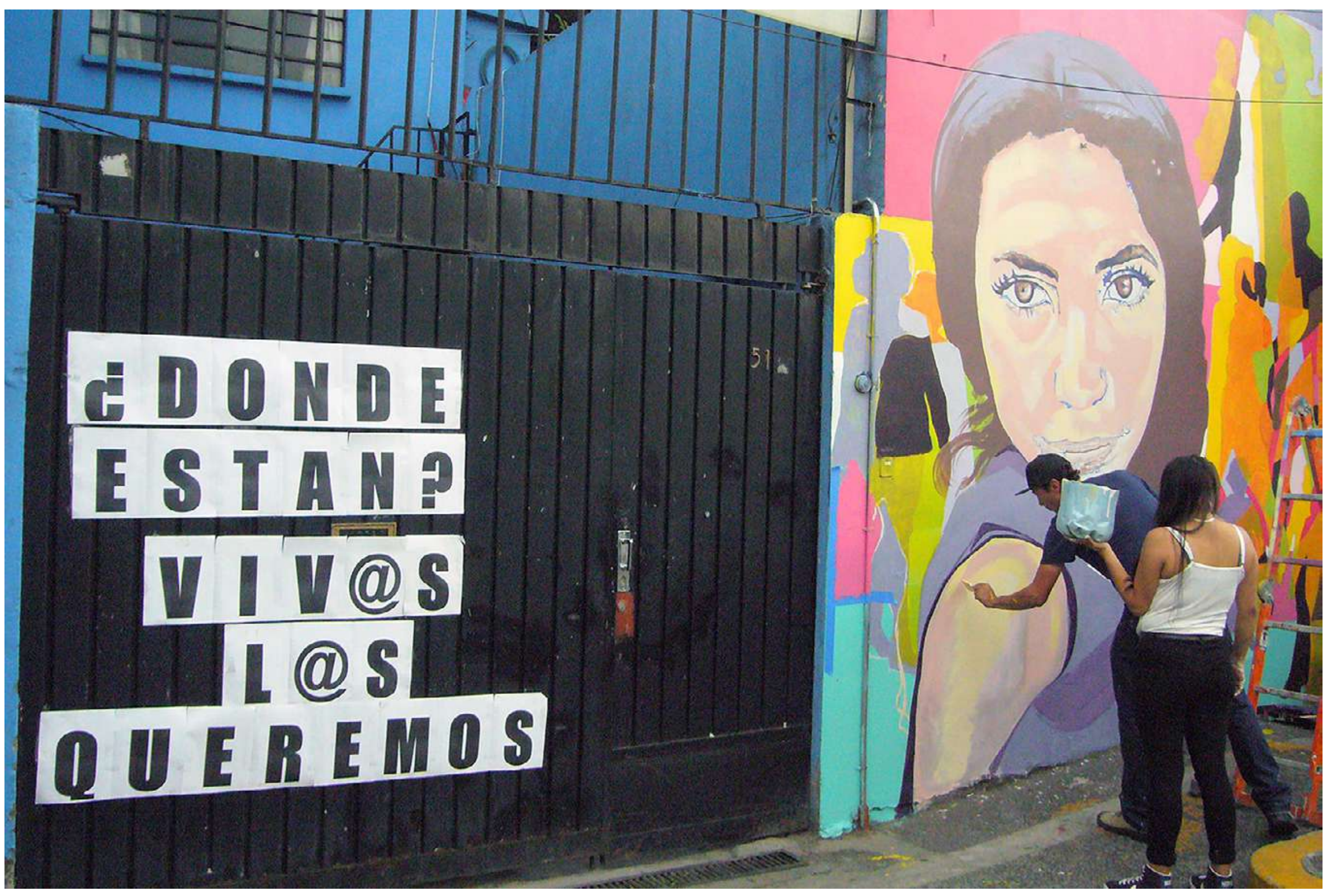

Muralismo y arte por nuestrxs desaparecidxs en coordinación con el colectivo Hasta Encontrarlxs CDMX, realizan murales en los lugares precisos de donde fueron desaparecidxs. Mural por Viviana Garrido en el metro Ermita, Ciudad de México, 30 mayo 2019.

Fuente: fotografía, Cristina Hijar González 


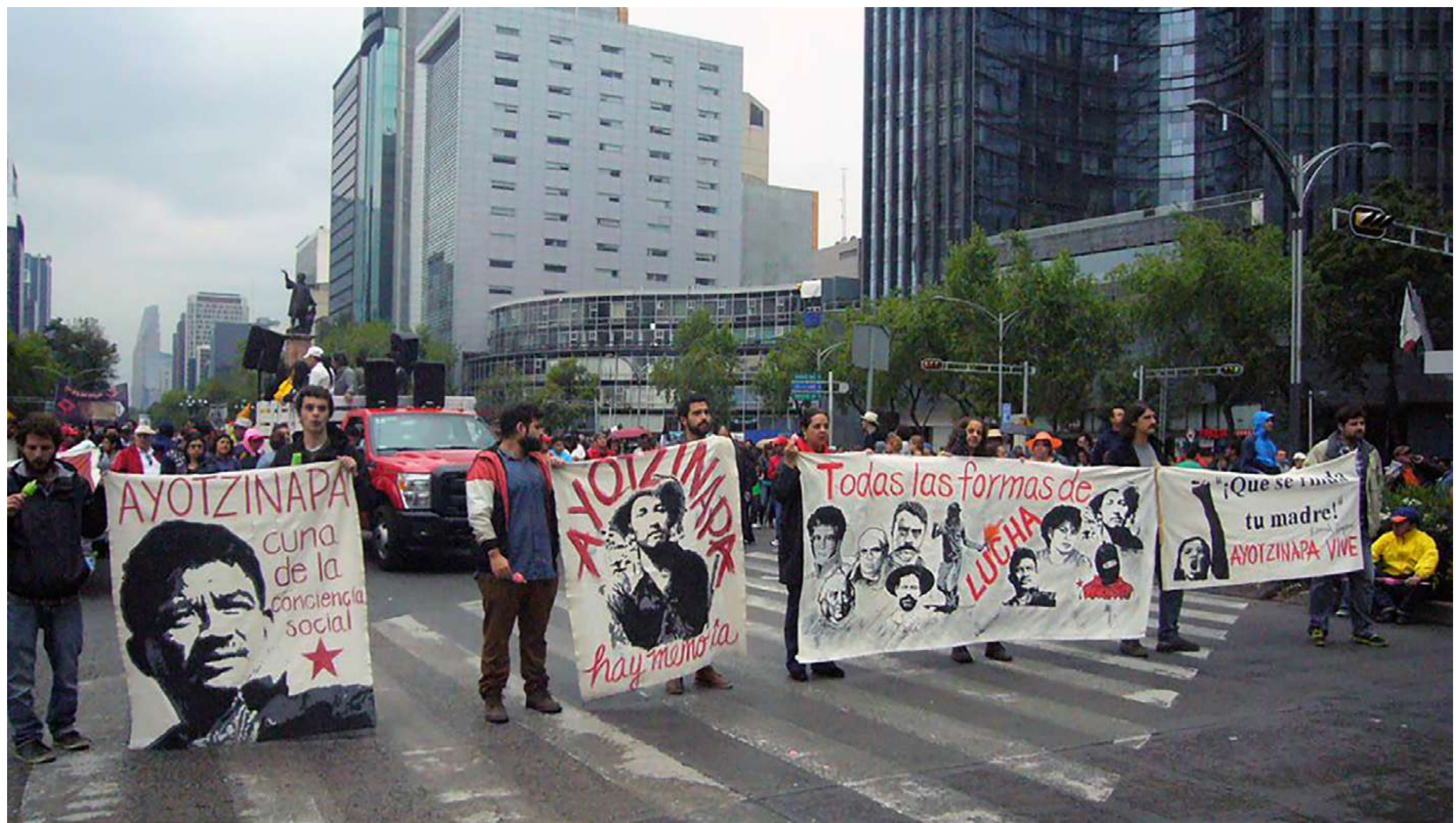

Mantas del Colectivo Híjar (por la memoria histórica) en marcha por Ayotzinapa, Ciudad de México, 17 julio 2017. Fuente: fotografía, Cristina Hijar González 


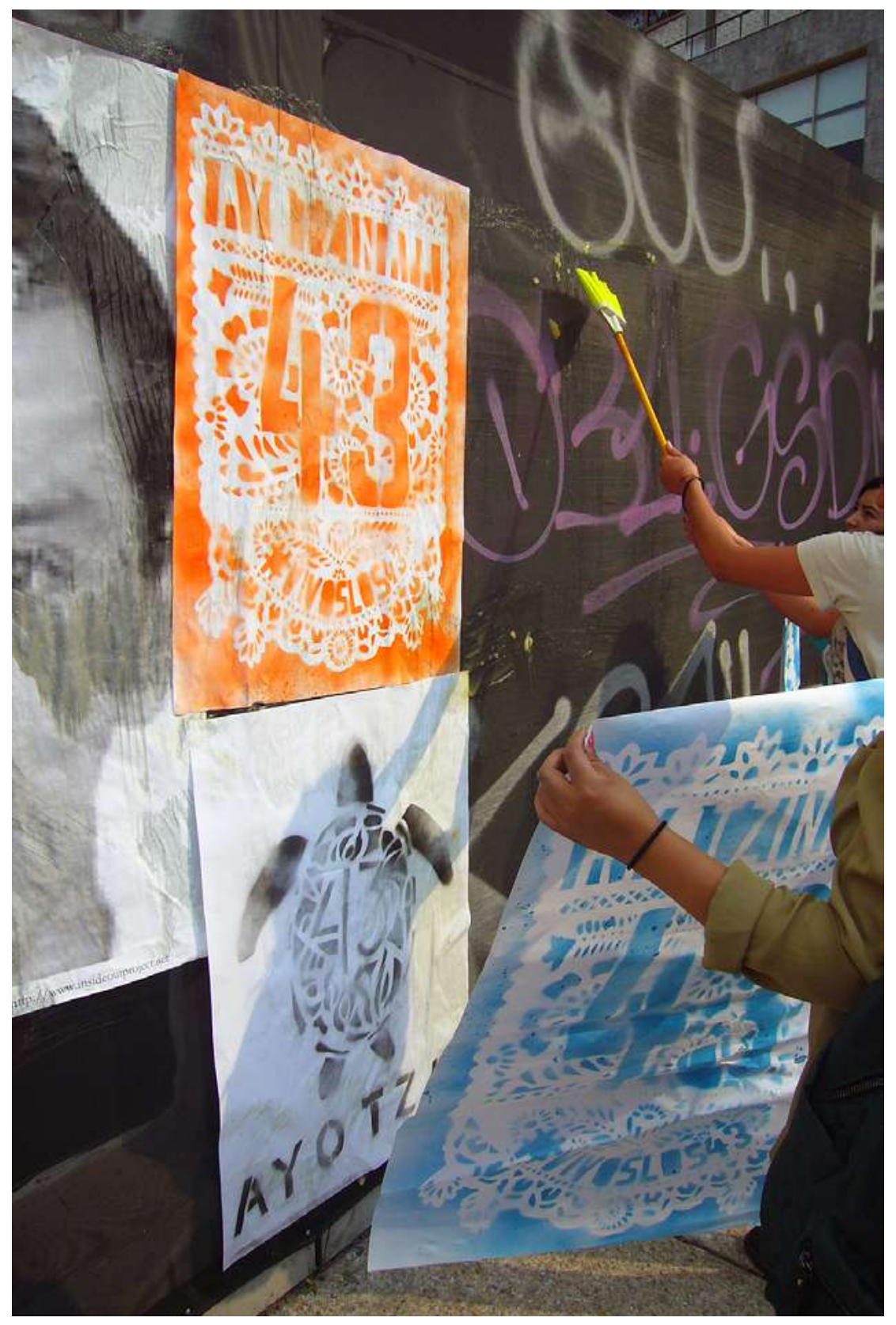

Pega de retratos y carteles durante la Jornada de Acción Global por Ayotzinapa, Paseo de la Reforma, Ciudad de México, 26 abril 2018.

Fuente: fotografía, Cristina Hijar González 


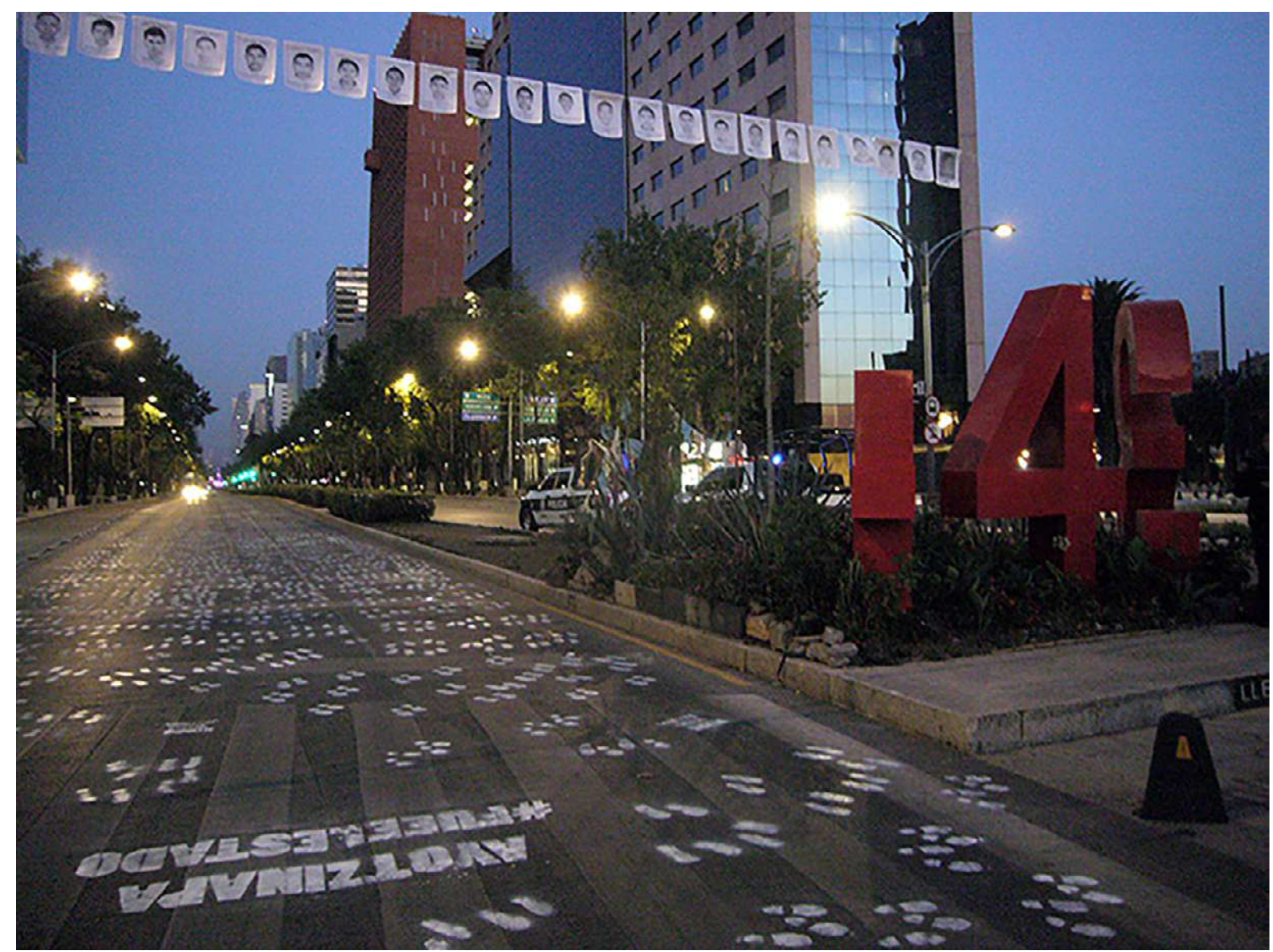

Acción gráfica colectiva y marcha simbólica por Ayotzinapa durante la pandemia. Ciudad de México, 26 mayo 2020.

Fuente: fotografía, Cristina Hijar González 


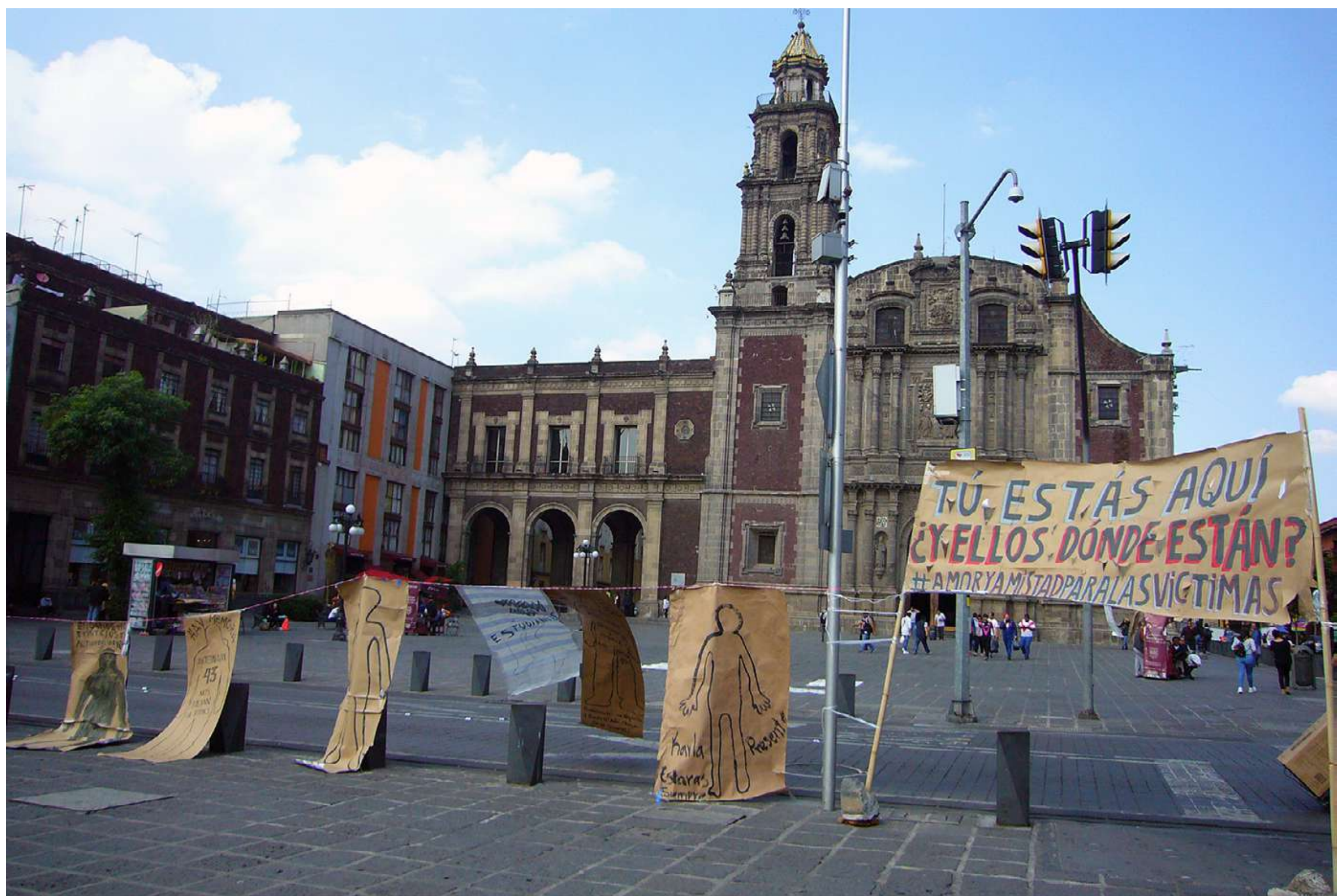

Siluetas por lxs desaparecidxs en la Plaza de Santo Domingo, Ciudad de México, 14 febrero 2018 Fuente: fotografía, Cristina Hijar González 


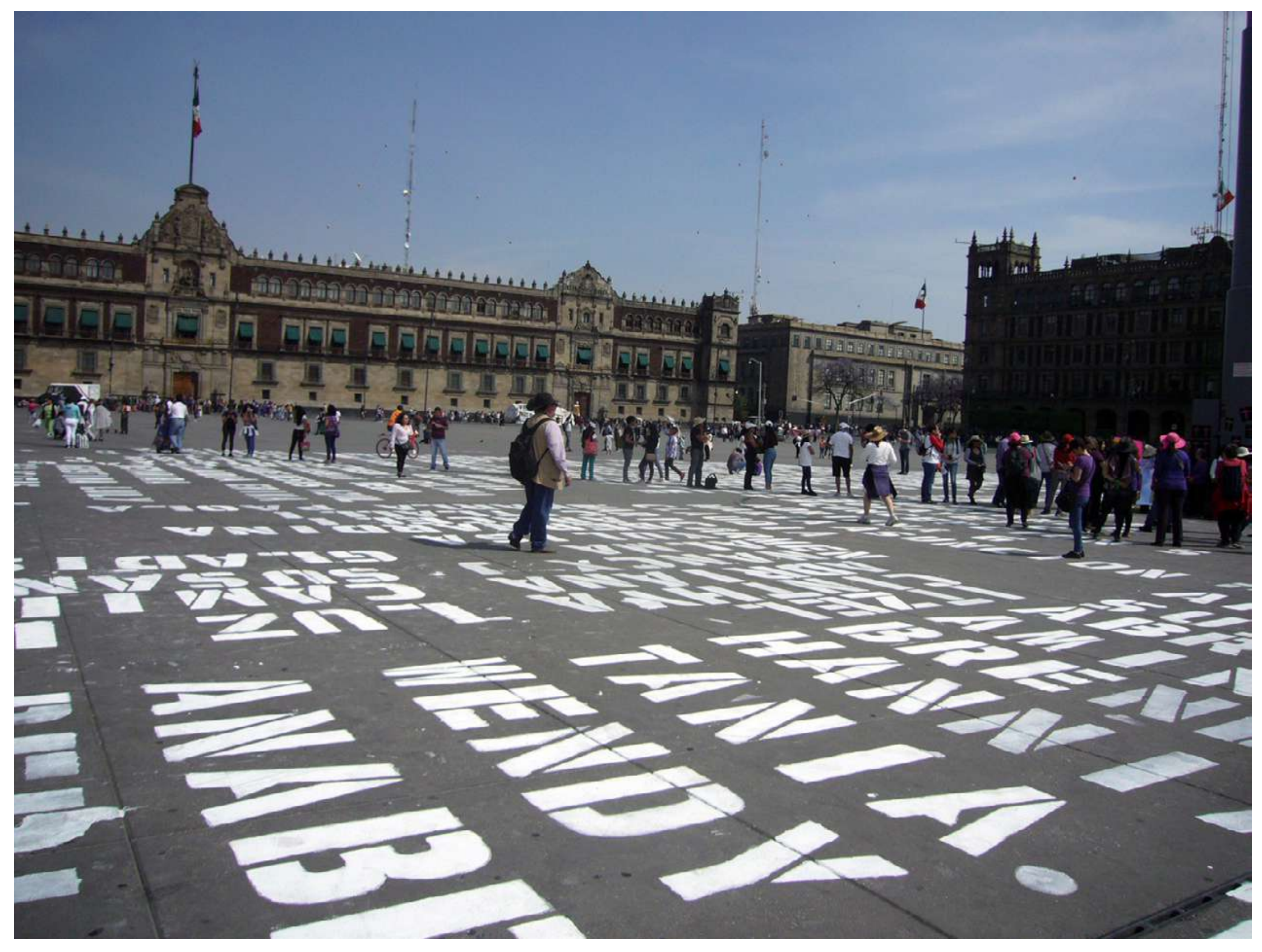

Pinta monumental de colectiva feminista en la plancha del zócalo de la Ciudad de México, con los nombres de víctimas de feminicidio, 8 marzo 2020

Fuente: fotografía, Cristina Hijar González 


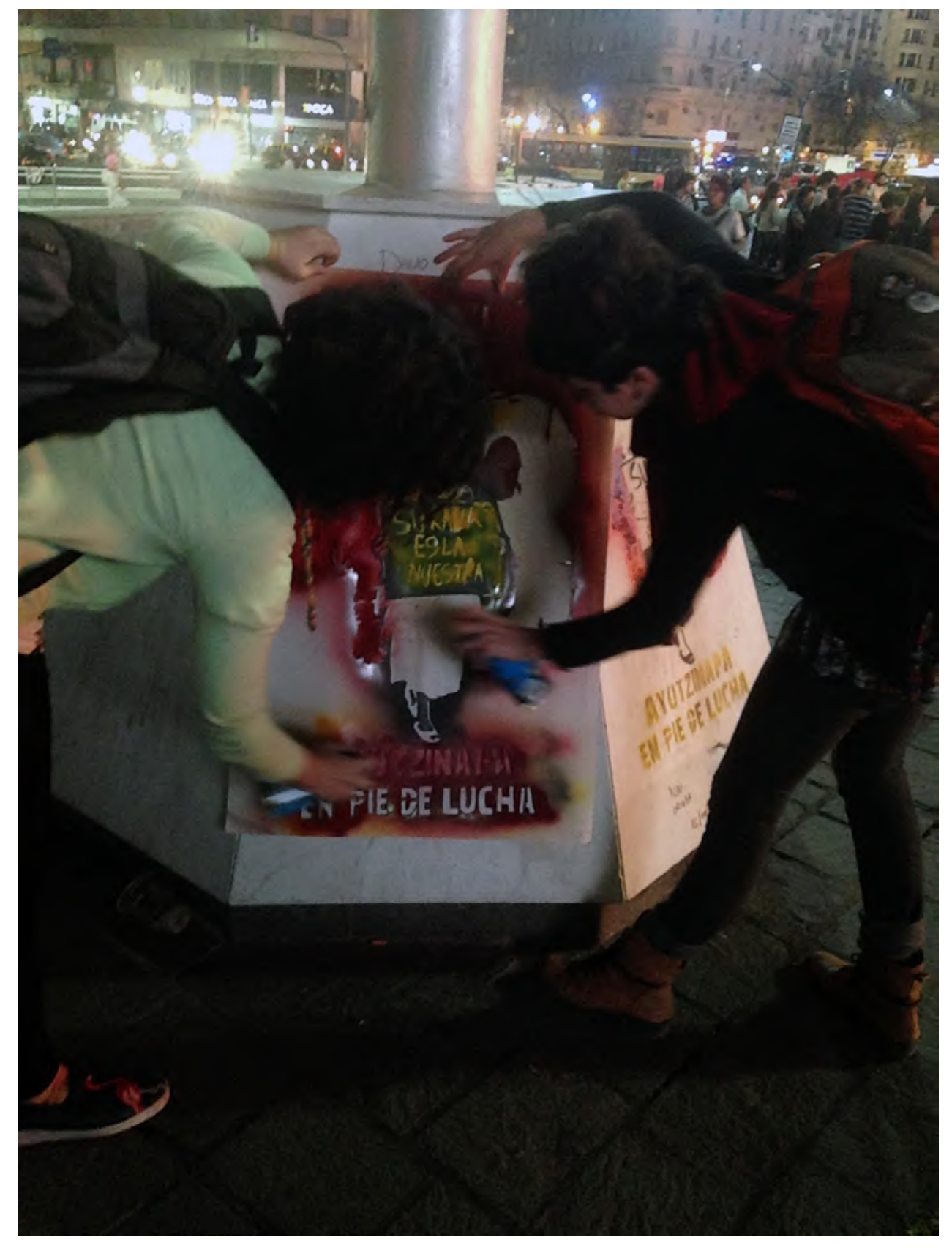

Plantilla por Ayotzinapa en metro Insurgentes, Ciudad de México, 5 noviembre 2014. Fuente: fotografía, Cristina Hijar González 


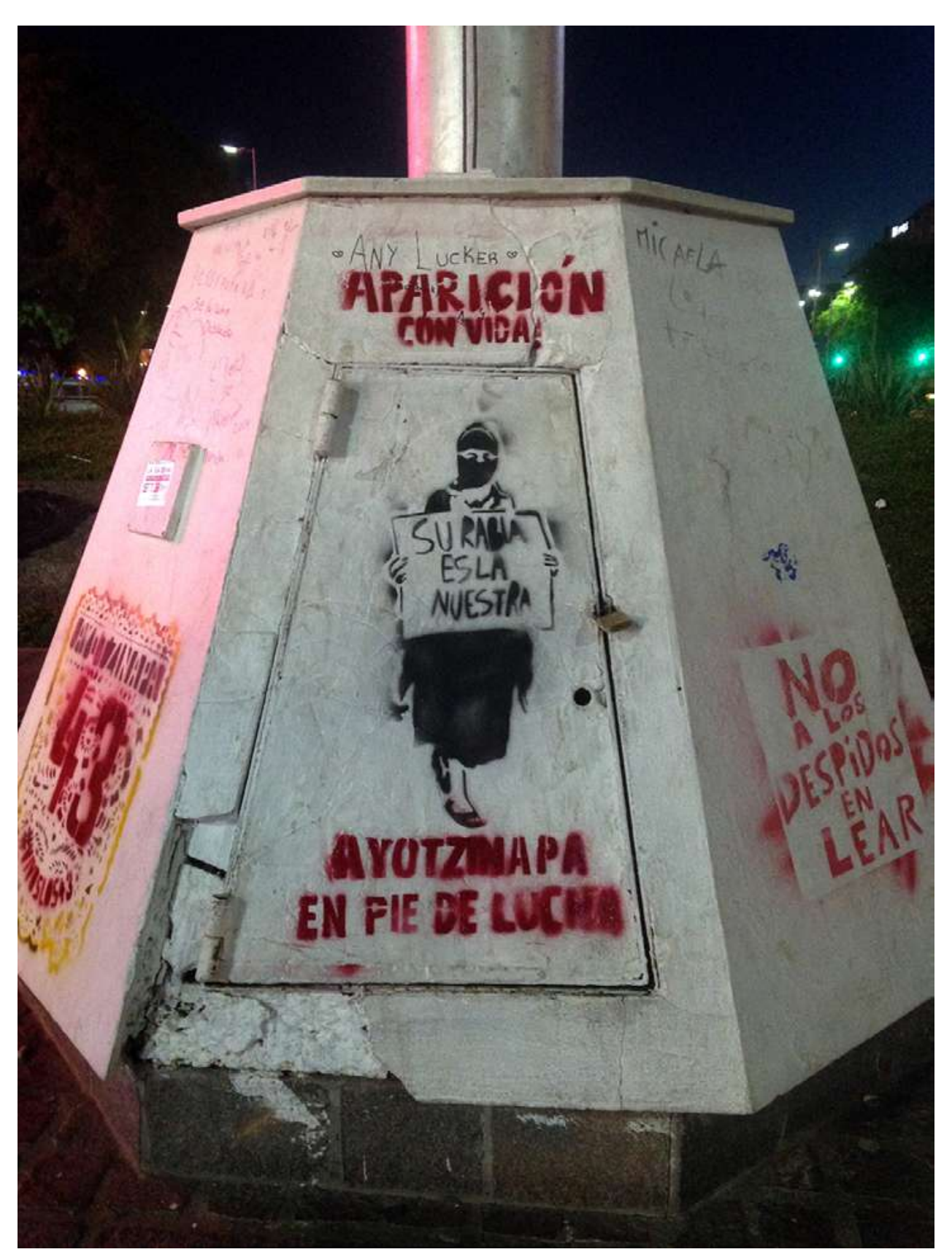

Plantilla por Ayotzinapa en metro Insurgentes, Ciudad de México, 5 noviembre 2014. Fuente: fotografía, Cristina Hijar González 


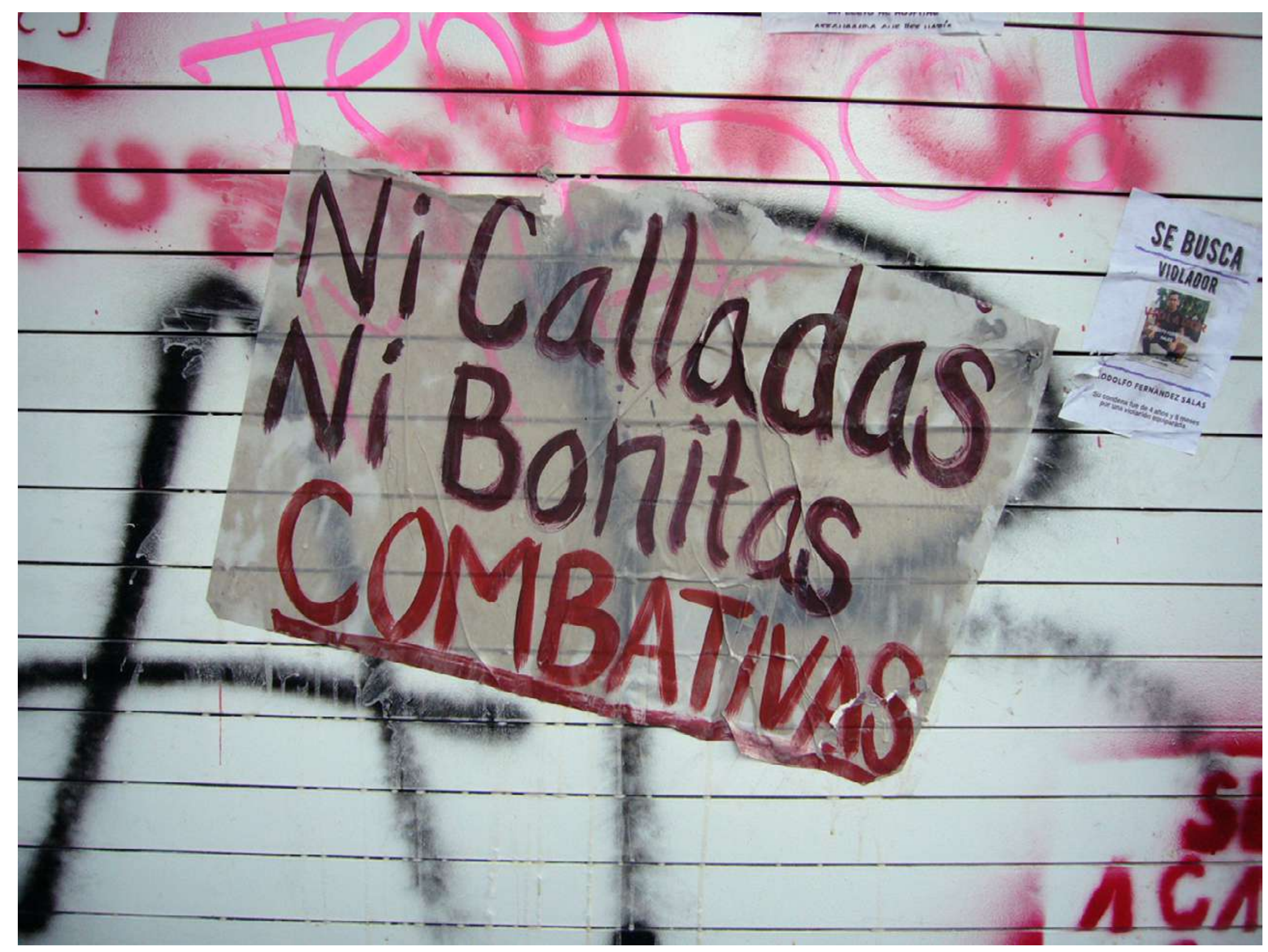

Pega feminista, Ciudad de México, 8 marzo 2020.

Fuente: fotografía, Cristina Hijar González 


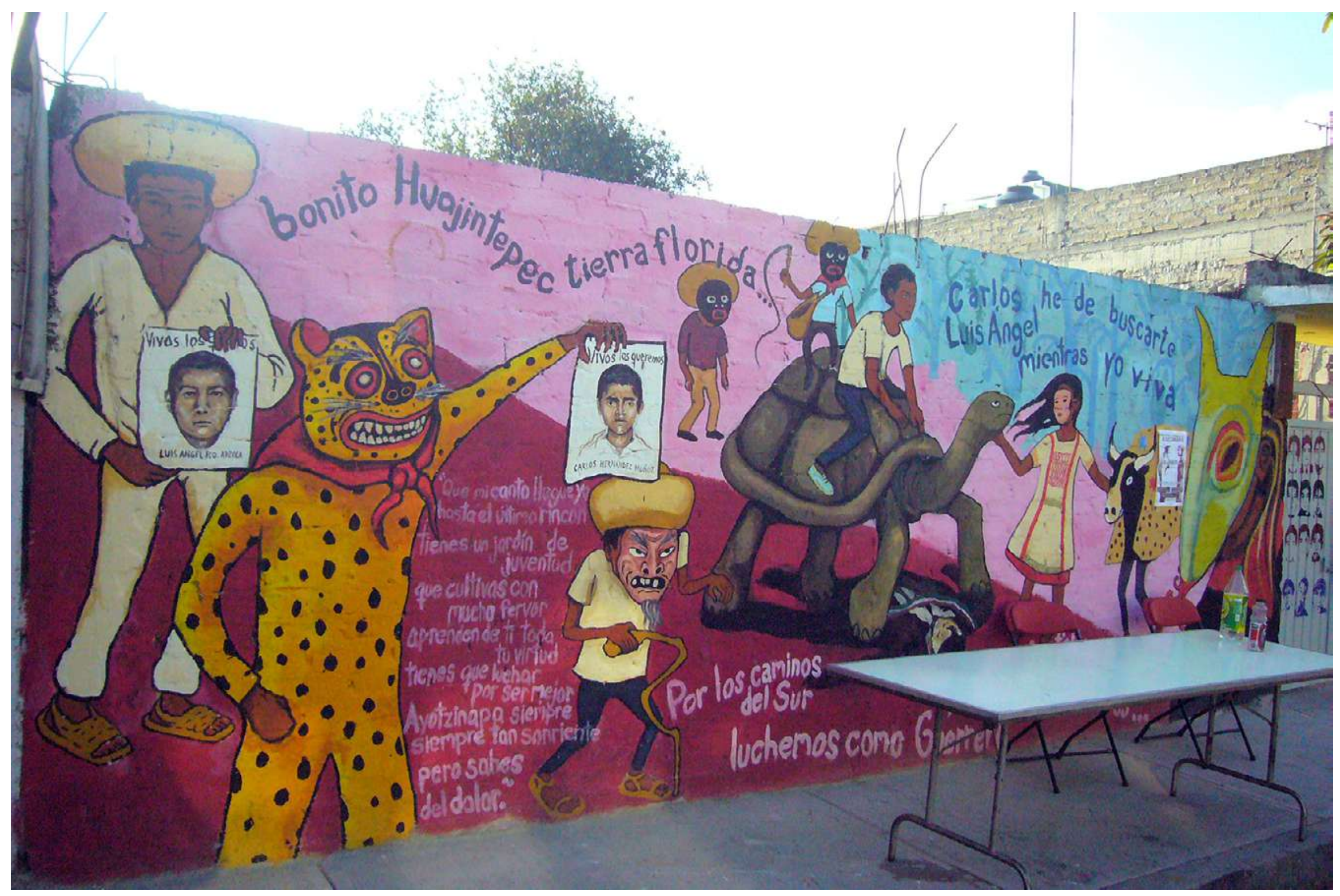

Mural de realización colectiva para Carlos y Luis Ángel, dos de los 43 detenidos-desaparecidos de Ayotzinapa, en casa particular en los Pedregales de Coyoacán, 25 abril 2015.

Fuente: fotografía, Cristina Hijar González 


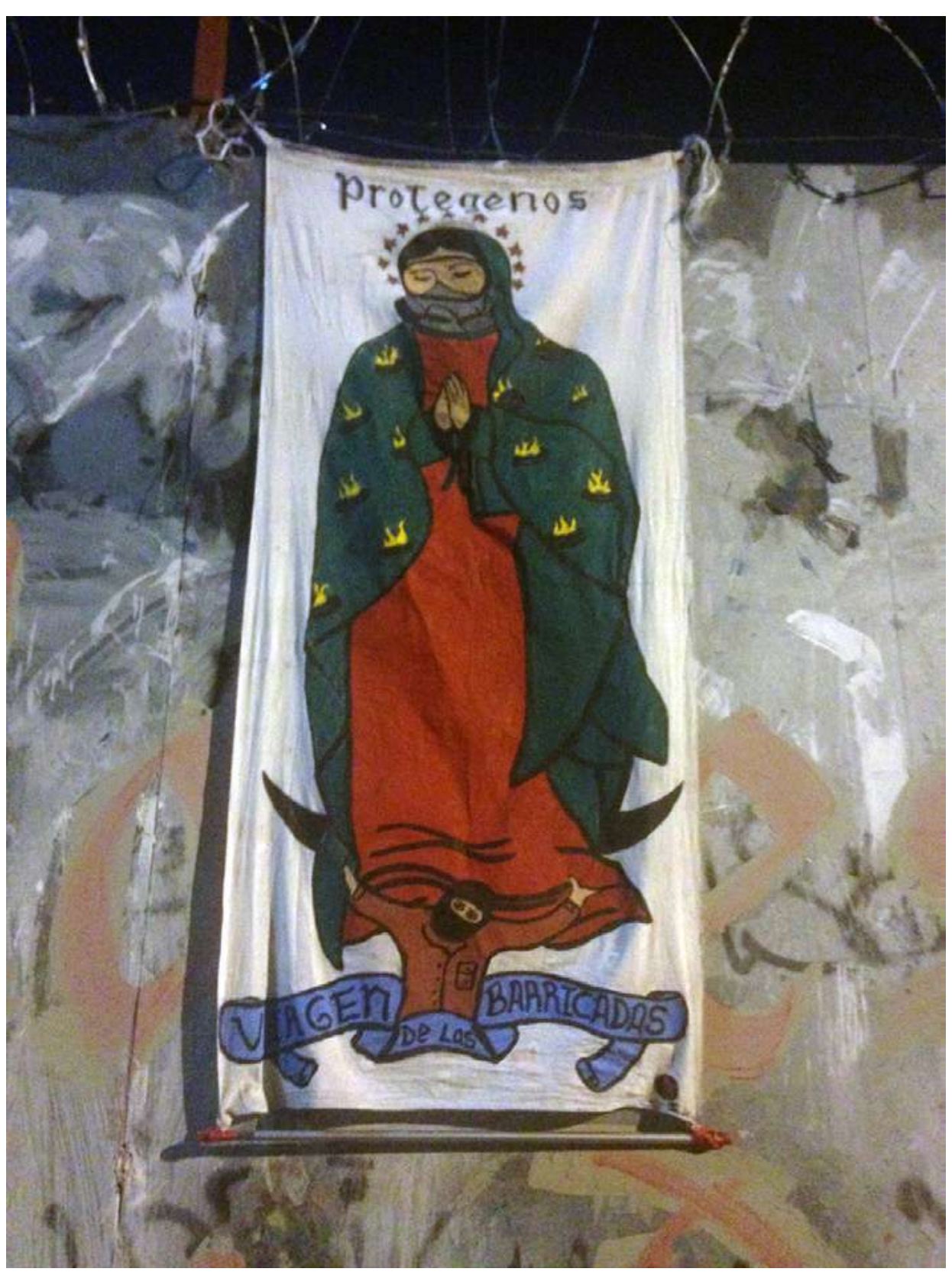

Vírgen de las Barricadas en el plantón en defensa del agua en Aztecas 215, Asamblea General de los Pueblos, Barrios, Colonias y Pedregales de Coyoacán, Ciudad de México, 22 diciembre 2017.

Fuente: fotografía, Cristina Híjar González 


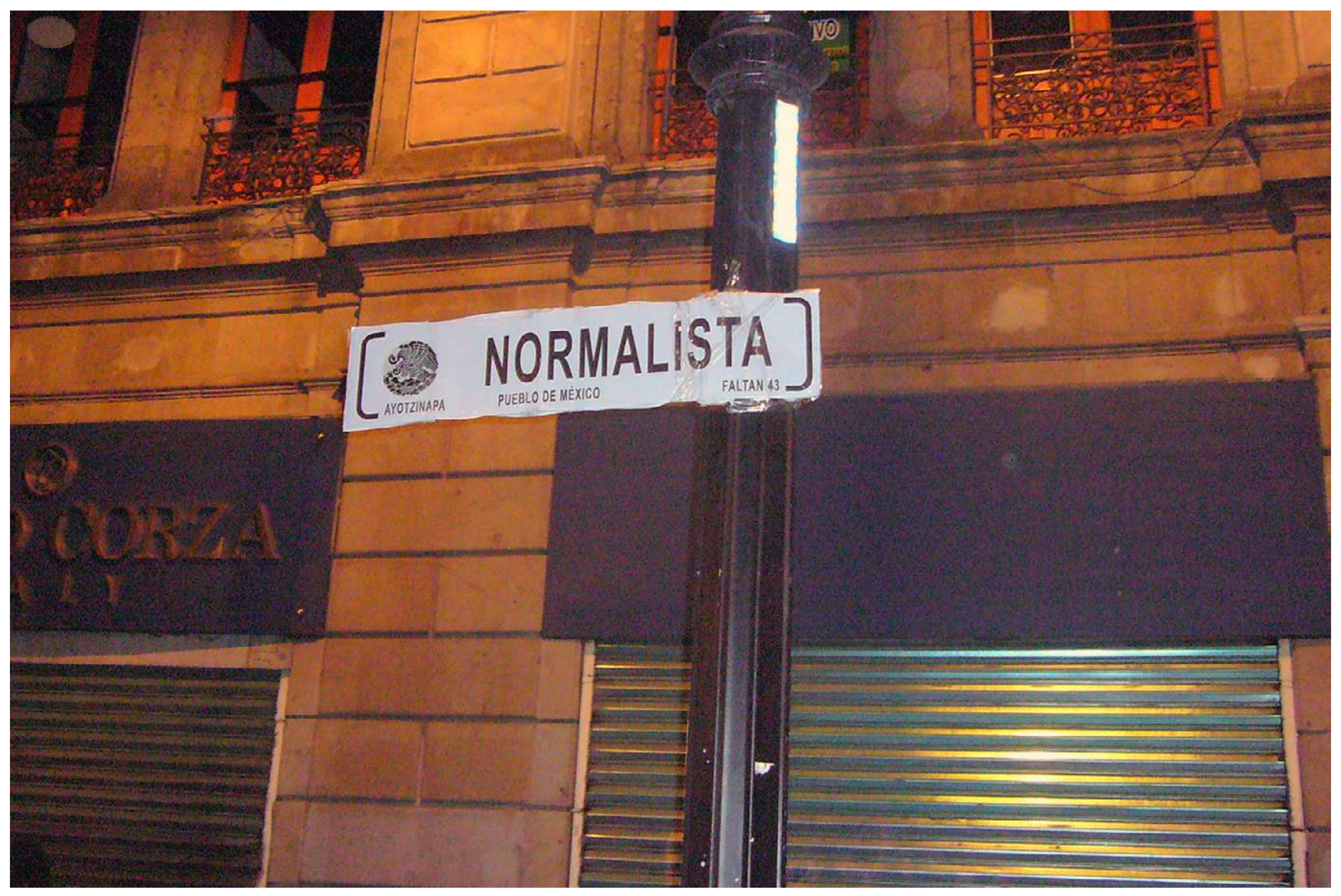

Acción gráfica de renombramiento de calles en el Centro Histórico de la Ciudad de México, 20 noviembre 2014. Fuente: fotografía, Cristina Hijar González 


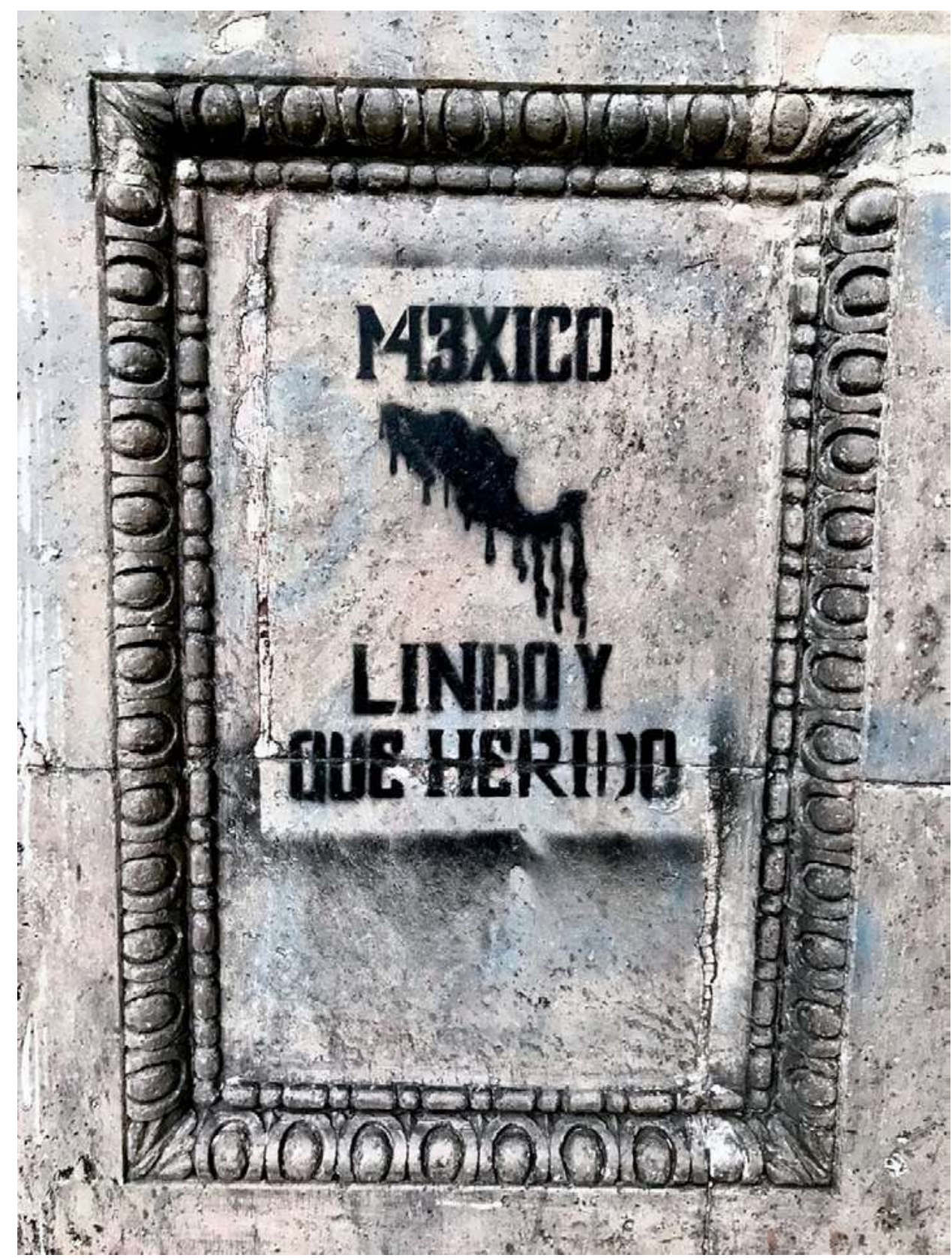

Esténcil colocado en base de estatua sobre Paseo de la Reforma, Ciudad de México, 6 febrero 2020. Fuente: fotografía, Cristina Hijar González 